\title{
The Depopulation of Upper Amazonia in Colonial Times ${ }^{1}$
}

\author{
por \\ Massimo Livi-Bacci \\ University of Florence \\ livi@disia.unifi.it
}

In Upper Amazonia, after an initial disastrous penetration of Spanish colonists, the Jesuits began the task of evangelization in 1638. A network of Missions covered the territory and some statistics were collected. The indigenous demographic system was characterized by high mobility and high fragmentation of the various communities, as well as rapid turnover of the missions' population. The Iberian intrusion increased the fragmentation, and many nations migrated away from the riverine areas (várzea) into the rainforest, with less favorable living conditions. This process may have pushed a number of communities under the threshold of minimum size for viability, thus accelerating the demographic collapse.

Key words: Upper Amazonia; Mainas; Missions; Demography; Mobility; Population decline.

\section{The Depopulation of Upper Amazonia in Colonial Times}

The collapse of the native populations of America in the aftermath of the contact with the Europeans is a well-established fact, but deep divergences among the scholars persist as to the causal factors and the violence of the

\footnotetext{
${ }^{1}$ I would like to extend my particular thanks to Ann Golob, who has generously donated to me a great number of precious transcriptions of archival documents she had gathered while preparing her doctoral dissertation in anthropology (The Upper Amazon in historical perspective, Ph.D thesis, City University of New York, 1982), a fundamental work for the knowledge of the Upper Amazon. Ann Golob has since left the field of anthropology -at the great regret of those who esteem her work- in order to pursue other interests. I wish to express to her my deepest gratitude.
} 
catastrophe. ${ }^{2}$ This is not surprising, because the encounter between the native societies -characterized by a plurality of social, economic and political structures and shaped by their peculiar environments and constraints- and the Iberian intruders, with their adaptable strategies of domination, could not possibly result in a uniform model of depopulation. Indeed several paradigms of disaster can be identified, apart from the epidemiological one that, in its most extreme formulation, attributes the catastrophe, almost entirely, to the new Eurasian pathologies. The Caribbean paradigm led to the extinction of the natives because the Conquerors imposed a sort of "prey-predator" model that implied the massive dislocation of the Tainos, who were forced to toil in the gold yielding areas, which disrupted their social fabric. ${ }^{3}$ Similar disasters took place in other regions where gold was found, in Castilla de Oro, in Colombia, in Peru. In Mesoamerica, depopulation was more catastrophic in the Atlantic lowlands than on the Meseta -perhaps because of the impact of malaria imported from Europe that thrived in this hot and humid environment-. The same can be said of the coastal areas of Peru, where the demographic collapse was much more pronounced than on the highlands. In these areas the conquerors imperiled a fragile economic equilibrium, often evicting the natives from the best land and diverting in their own favor the systems of irrigation. On the Andes highlands, where the majority of the population lived, the population decline in the two decades after the fateful assassination of Atahualpa at the hands of the Spaniards was more the consequence of the devastations of the civil wars ravaging the country, than the effect of new diseases. The same physical geography of Peru, the very high altitudes of the plateau and the comb-like configuration of the steep ridges and deep valleys from the Andes to the Pacific, may have kept in check the diffusion and the incidence of epidemics and lessened their

2 There is a general agreement that America's population suffered an acute demographic decline during the first century after contact. But the agreement ends here, because the assessments of initial population size differ enormously (some of them are rather bizarre). David Henige has coined the expression of "high counters" and "low counters" applied to the authors of contact estimates; these, in some cases, appear to be inspired more by pre-conceived considerations rather than by objective facts. (Henige, 1998). Henry Dobyns, half a century ago, issued a vigorous statement of the epidemiological paradigm, and the depopulation ratio of 1:20 between first contact and the demographic nadir that he hypothesized, has been a-critically accepted by several authors writing about the American indigenous catastrophe (Dobyns, 1996).

3 The "prey-predator" model was originally applied to fisheries and animal populations. Predators increase with the abundance of preys, but the decline of the stock of the latter is followed by the decline of the predators; the cycle starts again when the preys' stock is replenished. The application of the model to the Caribbean area where the preys (the Tainos) became extinguished and were substituted by African slaves is only metaphorical (Lotka, 1925. Volterra, 1928). 
demographic impact. On the other hand, their impact seems to have been more severe on the Mexican meseta than in the Andean highlands, perhaps because their diffusion into the periphery of the Empire had been accelerated by the highway system radiating from Mexico city, which was the main terminal of the flow of people -as well as of animals and plants- coming from Spain. ${ }^{4}$

In the following pages, the Amazonian catastrophe will be discussed. Beside the obvious impact of Eurasian pathologies, other factors will be discussed. These include the Iberian intrusion among the highly mobile riverine populations, the entradas, the slave raids, and general dislocation of the native population.

But two additional aspects are peculiar to the Amazonian paradigm, the first being the retreat of the riverine populations into the selva's (rainforest) uplands, out of reach of the Iberians and into a less favourable environment. By so doing many groups abandoned the cultivation in the fertile and seasonally inundated margins of the rivers, and reverted to hunting, fishing and gathering. The second aspect consists in the fragmentation of the already small ethnic groups, and the fall of many of them below the vital "minimum" sustainable number, that raised the risks of extinction of the smaller communities, thus contributing to the collapse.

\section{ON THE POPUlation of AMAZONIA, $16^{\mathrm{TH}}$ TO $18^{\mathrm{TH}}$ CENTURIES}

Beteween 1647 and 1649, the Franciscan friar Laureano de la Cruz, and two lay brothers of the same order, spent almost three years among the Omaguas, one of the most structured tribes of the Amazon (which will also be referred here as "the River"). ${ }^{5}$ At the time of Laureano's visit, the Omaguas lived in the many islands that dotted the River between the confluence with the Napo and that with the Putumayo; their settlement was relatively recent, consequence of the escape from the westward push of the slaving incursions carried out by the Portuguese of the Parà region. Laureano provides information on the number of houses and families, as well as the approximate extension of land, for six of the few dozen islands inhabited by the Omaguas. His information offers a population density of 4-5 inhabitants per square kilometer. If we extend this density to the entire várzea -the land several miles deep on each side of the main course of the River (as well as of its main tributaries), that

${ }^{4}$ It is impossible to summarize the rich wealth of studies behind the synthesis of the various paradigms of population decline given below. For an articulate discussion see Denevan (1992) as well as my own discussion (Livi-Bacci, 2008).

5 Laureano de la Cruz, 1900 (1651). 
was regularly flooded during the rainy season- there would be a total population in the riverine Amazonia of several hundred thousand inhabitants. It is assumed that the majority of the population of the Amazonian basin lived in the várzea (60 to 120,000 square kilometers, or between 1 and 2 percent of the entire basin); its land was fertilized by the rivers' inundations and provided rich crops of staple food such as maize, manioc or squash; moreover fishing was easy and abundant. It is also fair to assume that the Omaguas, being an enterprising and laborious community, had a higher than average density with respect to the other riverine ethnic groups, so that extending their density to the entire várzea gives a maximum guesstimate of the population settled along the River's banks. On the other hand, the peoples of the rest of Amazonia (98 to $99 \%$ of the basin's extension), living in the interfluvial selva and removed from the major rivers, drew their subsistence from a much less generous environment, and therefore had a much lower population density. Adding to this -relatively- densely settled várzea, the rest of the population of the Amazonian basin (with a density lower by at least one order of magnitude), would make the word "million" fitting reference of the total population. ${ }^{6}$

${ }^{6}$ I am following here the calculations made by Denevan (1992), the most accurate and experienced scholar dealing with an interdisciplinary estimate of the Amazonian population, These calculations provide useful orders of magnitude for densities and population at mid-1 $7^{\text {th }}$ century. For the Omaguas' islands, Denevan calculates a density of about (I am rounding the numbers) 5 inhabitants per $\mathrm{km}^{2}$ that he extends to the whole floodplains (várzea). Assuming a surface of the várzea of $100,000 \mathrm{~km}^{2}$, this density yields a total population of 0.5 milion at Laureano's times. For the rest of the Amazon basin (98.5 percent of the total surface of over 6 million $\mathrm{km}^{2}$ ) Denevan estimated an average density (densities varied according to the various ecological zones) of a fraction of one percent $(0,2)$, yielding a total population of 1.2 million; adding the 0.5 of the varzea the total population becomes 1.7 million. But what about the population at contact, one or more century before Laureano? Denevan assumes that a collapse had taken place, that had greatly diminished the total population, and therefore inflates the estimate of mid-1 $7^{\text {th }}$ century by a factor of 3.5 (corresponding to a population decline of 71.4 percent). “...population figures of the central and upper Amazon area for the mid-seventeenth century....can be increased at least 3.5 times for the contact period 100 years earlier" (Denevan, 1992: 212), After minor adjustments and revisions, Denevan comes up with a total population at contact between 5 and 6 million (ibidem: xxviii and 234). It is the hypothesis of a disastrous collapse -and its quantification- that is critically discussed in the following pages.

The same Denevan, in a recent reassessment, somehow regretted the "false" precision of the estimates: “... I now reject the often cited habitat-density method I used in the past to estimate a Greater Amazonia population in $1492 \ldots$ There was too much variability in densities in each habitat to be able to formulate meaningful average densities on the basis of a few sample densities". However, "I have some perspective from all these years of attempting to make estimates; from having examined and reexamined the relevant archeological, historical, environmental, and agricultural evidence; from being familiar with the methods and the estimates of others; and from having conducted fieldwork on several Indian groups...This 
The mid-seventeenth century situation is a convenient starting point for our analysis. It is midway point between the first Iberian navigation of the Amazon from the Andes to the Atlantic Ocean undertaken (almost by accident) by Orellana and 54 companions in 1541-42, and the expulsion of the Jesuits from Spain's colonies in 1767. Their eviction put a stop to their effort of evangelization among the Upper Amazonian natives. By mid- $18^{\text {th }}$ century the depopulation of Amazonia was evident. Among the numberless testimonies, Charles de la Condamine' synthesis is worth quoting: "only a century ago, the banks of the Marañon were inhabited by a great number of nations that retreated in the interior as soon as they saw the Europeans. One encounters, today, only a small number of villages of natives, only recently brought from the interior of the forest, themselves or their fathers, some from the Spanish missionaries in the upriver course, some from the Portuguese missionaries, in the downriver tract". ${ }^{7}$ La Condamine navigated the River in 1743 returning to Paris from Peru, where he had led an official scientific mission.

Many believe that the catastrophe of the riverine populations had begun in the $16^{\text {th }}$ century and that a century later -when Laureano visited the Omaguasthe population must have been a fraction of its size at contact. ${ }^{8}$ The testimonies rendered in writing by the companions of Orellana and -twenty years laterUrzua and Lope de Aguirre's expeditions, narrated of long stretches of the River settled by villages, of multitudes of natives, and has led to the belief that, at contact, the Amazon's banks had a relatively dense population. But a careful analysis of those texts discovers also that the River was deserted for at least one third of its length, and that the first explorers suffered intense hunger during the long months of their navigation: their main source of sustenance was the food raided in the villages encountered in their descent of the River, that probably were neither frequent nor large. ${ }^{9}$ Until the mid- $17^{\text {th }}$ century, contacts with the Europeans had been sporadic, with the exception of the Spaniards in

perspective...gives me confidence that the Indian population in 1492 was indeed at least 5 to 6 million for Greater Amazonia..." (Denevan, 2014: 211).

An accurate analysis of the location and habitat of the Omaguas' islands in the River, and an estimate of their density, can be found in Porro, 1981.

${ }^{7}$ La Condamine, 1745 (1981).

${ }^{8}$ Denevan assumed a depopulation ratio of 1:3.5 for the Amazonian floodplains; other less prudent authors have assumed bizarre and inconsistent implicit ratios (Myers, set the Omagua population at 2 million in 1524, and accepted an estimate of 5,500 for mid-xvii century, with an implicit depopulation ratio of 2.75:1000!) (Denevan, 1992: xxvi).

9 The chronicle of Orellana's navigation was written by Fray Gaspar de Carvajal, 1986. Chronicles of Urzua's and Aguirre's navigation were written by Pedro Arias de Almesto, and by Francisco Vazquez, 1986. For a detailed analysis of the texts, in a demographic perspective, see Livi-Bacci, 2012: 41-55 and 59-71. 
the eastern slopes of the Andes and a few adventurers from Atlantic Europe on the banks of the estuary. Until then, Eurasian pathologies, slaving raids, forced labor and dislocation -the main scourges of the natives after contacthad been rare. The road to disaster probably steepened its course in the central decades of the $17^{\text {th }}$ century, when the River had ceased to be an immense and mysterious waterway to be explored, and had become an accessible -although risky- pathway for Iberian merchants, soldiers, raiders and missionaries. Once the contagion had spread among a tribe's members, their high mobility and the frequent intertribal contacts implied a further diffusion of the pathology. But the low density of the Amazonian populations meant also that the epidemics would burn out, and for a new epidemic to take place, the virus had to be reintroduced from the exterior. A question remains unsolved: when were the Amazonian populations first infected by the new pathologies? Can we assume that they regularly afflicted the riverine populations before contacts with the Iberians ceased to be sporadic in the $17^{\text {th }}$ century?

\section{UpPer Amazonia AND Mainas}

Upper Amazonia is a vast expanse of land extending from the crest of the Andes to the foot of the mountain chain and, further east, to the upper course of the Great River. In the following pages, I will deal with the demographic aspects of this region, which in the $17^{\text {th }}$ and $18^{\text {th }}$ centuries was known as Mainas, after the name of one of the many ethnic groups -or tribes/nationsas they came to be named. It can be described as an irregular triangle, the base on the foot of the Andes and the top at the confluence of the Amazon with his southern tributary Javarí, approximately where Colombia and Peru border with Brazil. The course of the Putumayo defines the northern border of Mainas and that of the Javarí the southern one (figures 1 and 2). The base of the triangle -along the Andes- extends for approximately 700 kilometers (from the equator to $6^{\circ}$ South), while the vertical axis extends for about 1000 kilometers $\left(70^{\circ}\right.$ to $78^{\circ}$ longitude West); the entire surface is roughly the same size as the Iberian peninsula. ${ }^{10}$

Only a few years after Atahualpa was murdered at Cajamarca, several Spanish expeditions (the most famous ones being those by Pizarro-Orellana

${ }^{10}$ Mainas' borders given in the text are grossly indicative, given the high mobility of the indigenous populations and the imperfect knowledge that administrators and missionaries had of the geography of the Upper Amazonian region. The surface of the Iberian peninsula is $600,000 \mathrm{~km}^{2}$. 
Figure 1. Upper Amazonia and Mainas

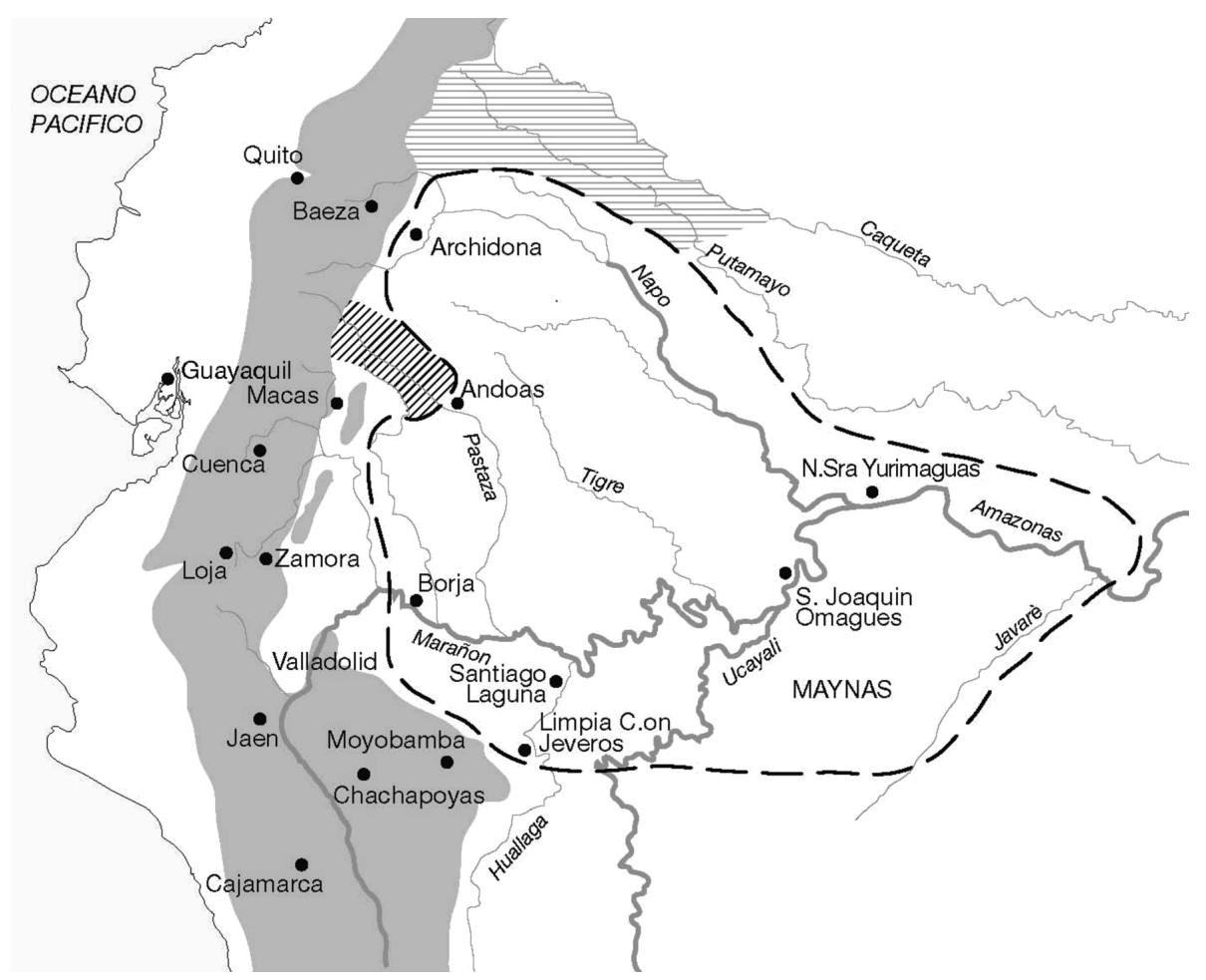

Caption: Borders of Mainas.

and Urzua and Lope de Aguirre, which have been referred to before) attempted to cross the Andes and explore the eastern reaches of the Cordillera. A stable Spanish presence in the eastern slopes of the Andes began in the ' 70 s and ' 80 s of the $16^{\text {th }}$ century, when several gold placers were found and a few, often ephemeral, settlements founded: Sevilla de Oro, Logroño, Zamora, Valladolid. Gold prospection was very labor intensive and soon the harsh exploitation of Indian labor led to bloody rebellions and bloodier repressions (1578 and 1599). In the district of Quijos -that rebelled in 1578- the population of indios tributarios declined by two thirds between 1576 and $1608 .{ }^{11}$

${ }^{11}$ Two official documents, of 1576 -two years before the rebellion- and of 1608, assign to the district 6,803 and 2,335 indios tributarios respectively, with a two thirds decline. The number of indios tributarios per Spanish encomendero fell by three fourths over the same period, from 166 to 42. Encomendero, holder of an encomienda, was a Spanish eminent colonist, holder of an encomienda, usually land with indios tributarios, who paid him a tribute in kind 
Figure 2. Major ethnic groups of Mainas

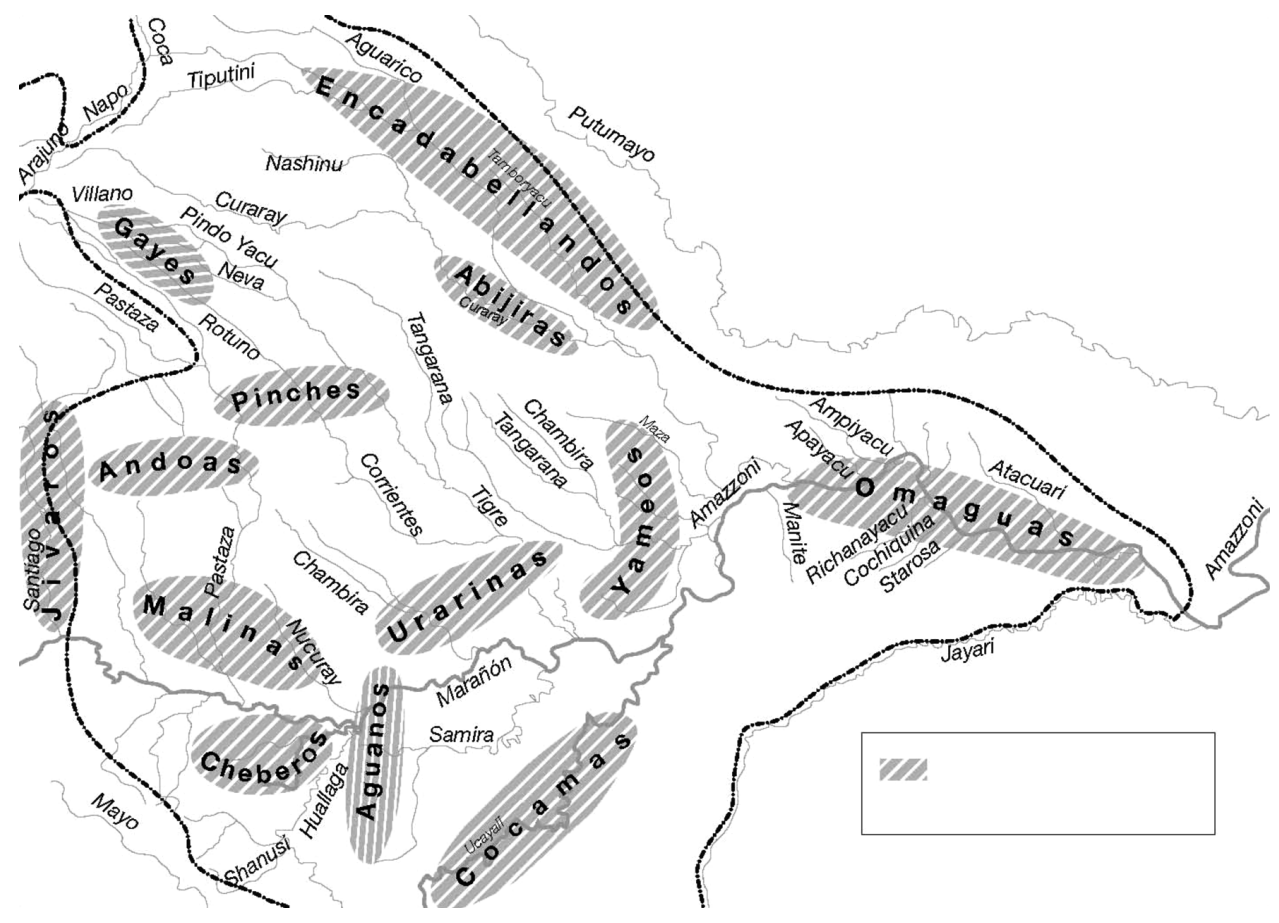

This was a typical example of the "gold paradigm" of demographic disaster caused by the contagion with the new diseases brought by the Spaniards, and the intensive and brutal exploitation of manpower, which resulted in displacement, flight and death. The intrusion of the Spaniards, and the conflicts that followed, determined a fracture in native society between the settlers of the plains and those of the mountains, related to the not infrequent contacts that preceded it. ${ }^{12}$ The eastern penetration of the Spaniards led to the foundation of the "city" of Borja in 1619 on the banks of the Marañon, just past the last turbulent rapids of the river through the Pongo ("gate" in quechua). There, a bloody rebellion of the Mainas against the Spaniards took place in 1635, followed by a devastating repression. It is in the aftermath of the rebellion, in 1638, that the first Jesuits arrived. These initiated a task of evangelization

or money, in return from protection and instruction. The documents were written by Diego Hortegón (Hortegón et al., 1989).

12 Taylor, 1999. 
that led to the foundation of dozens of missions in the following 130 years, until their expulsion from the Spanish colonies in $1767 .{ }^{13}$

The arrival of the Jesuits also implied the end of the penetration of Spanish colonists in Mainas: their presence was limited to Borja, which would remain the administrative center of the region, seat of a small garrison under the command of a Lieutenant, and of a few Spanish families. The missionaries -very few in numbers, as we will see- set to the desperate task of making contact with the plurality of ethnic groups; inducing them to abandon their settlements and accept to be "reduced" into new villages, or missions, on the model that was taking shape in other parts of America. The missions were organized under the unchallenged leadership of a father, sometimes assisted by a lay brother and a viracocha (mestizo). This task proved to be a sisyphean job. Among the many challenges was the paucity of missionaries, and the difficult and precarious communications with the faraway headquarters in Quito, across the Andes. ${ }^{14}$ The high mobility of the natives and their disperse settlement patterns greatly hampered the missionaries' plans. Ultimately, there was also deep mistrust which was nourished by past experiences, hence the frequent presence of soldiers accompanying the fathers in their initial

13 The history of the Jesuit evangelization in Mainas is mostly based on the writings of the Jesuits themselves, protagonists of the events. They are obviously influenced by the loyalty to their mission and have to be read and interpreted with care. Nevertheless they are almost the only source available. Among those authors who have lived the events narrated are: Figueroa, 1986 (1681). Maroni, 1989. Velasco, 1942. Chantre y Herrera, 1901 (1770). Chantre y Herrera never lived in America, but wrote his history in Faenza where he was advised by fathers like Uriarte and Iriarte, (exiled from Mainas into Italy). A very accurate modern history of the Jesuits in the Quito's region is given by Jouanen, 1941; 1943. Among more recent works: Sweet, 1974. Golob, 1982. Hemming, 2008.

${ }^{14}$ Communications between Mainas and Quito were slow and difficult. Travelers had to pass the crest of the Andes at over 13,000 feet of altitude, than they descended in the valley of the Rio Quijos to the villages of Baeza and Archidona; next they joined the Rio Coca and by canoe descended to the confluence with the Rio Napo which they had to navigate for about 400 miles until the confluence with the Amazon River. In order to reach Santiago de la Laguna, the main mission, the Amazon (or Marañon, because this was the name of the river in its upper course) had to be navigated upstream for another 400 miles, until the confluence with the Huallaga (southern tributary of the Great River), and upstream the Huallaga for a short distance. The trip took several weeks for the ordinary missionary who normally traveled with a lay brother, a viracocha and many indios for transporting the personal belongings and other necessities for the mission's life. Every year a transport (despacho) travelled from Quito past the Andes and plied the waters of the Mainas rivers in order to supply the missions with steel, tools, cloth, seeds, flour, even wine and religious objects. 
attempts of evangelization. ${ }^{15}$ This Jesuit campaign began in the district of Borja among the Mainas, and then developed in the lower course of the rivers Huallaga and Ucayali, southern tributaries of the Amazon, where some of the most numerous nations lived, such as the Cocamas and the Xeveros. On the banks of the northern tributaries of the Great River, the Tigre and the Curaray, other missions were founded. In 1670 Santiago de la Laguna was established on the Huallaga, close to the confluence with the Amazon, and this mission became the seat of the head of the fathers, and the main center of the region. After 1720, the missionary action reached the Napo and the middle course of the Amazon, an area that came to be known as Misión Baja (lower mission). It is in the central decades of the century that the Jesuits' effort reached its maximum in terms of personnel employed in the evangelization of the "heathens", the variety of tribes contacted, and the number of missions founded. Over the 130 year duration of the Jesuit presence in Mainas, there is evidence of the foundation of 152 missions, many of very ephemeral duration, most of the time very small outposts with a few dozen people; the average duration of a mission was 20 years, many lasting only a few months or years; only a handful lasted a century or more. Overseeing the missions' network, a total of 161 fathers, whose average permanence in the region was about 10 years. ${ }^{16}$ The number of fathers operating at any given time was below 10 until the end of the $17^{\text {th }}$ century, below 20 until mid- $18^{\text {th }}$ century, and reached a maximum of 30 in the final years: in 1768, 28 fathers were deported to Europe.

15 Many wise Jesuits, and the Superiors, warned against attempting entradas with numerous and visible soldier escorts, since these were often unruly and violent, which terrorized the natives, induced them to take flight in the forest. But many entradas ended in massacres and forceful capture of prisoners. Although things improved, the old habits proved hard to die.

${ }^{16}$ Ann Golob (Golob, 1982) has given an interesting anthropological portrait of the 161 Jesuit fathers during the 130 years of evangelization in Mainas. 62 were born in the Colony, 45 in Spain, 30 in Germany, 20 in Italy, 2 in Portugal, 1 in France and 1 in Hungary. Of the 20 Superiors that guided the Missions, only 3 were born in America (there were 4 American born out of 10 among the missionaries), perhaps a sign of the lesser consideration in which they were held by the hierarchy of the order. The order judged the Germans, followed by the Italians, as the more motivated and able missionaries: perhaps a selection factor played a role, given the distance of their culture from the Spanish one, a distance overcome only by those who were more attracted by a missionary experience in the New World. Every three years their standing was assessed by their superiors for what concerned ingenium, iuditium, prudentia, experientia and litera: $67 \%$ received positive marks for ingenium while only $23 \%$ received the same appreciation for prudentia and $14 \%$ for experientia. On average, they arrived in Mainas at the age of 30 and remained there 10 years; 9 were killed, others died in Mainas of other causes. A small group for an immense territory, poor in numbers but rich in human capital. 
The POPUlation OF MAINAS

During the 130 years of the Jesuits presence in Mainas, there were numerous signs of a population collapse. Father Figueroa noted that at the foundation of Borja, in 1619, 700 tributaries (indio heads of household, for a total number between 3 and 4 thousand souls) were distributed through encomienda to 21 Spaniards. In the following decades their number declined precipitously due to the vexations suffered; many escaped into the thick of the selva. All suffered a very high mortality, how much due to hardships and how much to the new pathologies cannot be said. "When the fathers arrived" there were only 400 tributaries, further reduced to 200 in $1661 .{ }^{17}$ At this latter date, the indios of the district of Borja where about 1,000, and some 500 were fugitives in the selva, confirming the fact that running away was a primary component of the demographic system of the region.

According to the same father Figueroa, the indios in the missions, in 1660 , numbered about 10,000 , but after the smallpox of that year, only 7,000 remained, of whom 3,100 had been baptized and the others were catechumenos. ${ }^{18}$ Only a fraction (between 10 and $20 \%$ ) of the total population of the region, that father Figueroa estimated in about 60,000, lived in the missions. ${ }^{19}$ Figueroa was a reliable observer: he thought that there were about 40 small different "nations" (ethnic groups, tribes) in the region, each numbering not more than 1,000 people, and only a score of them of larger dimensions. In his opinion, since the first entrada (expedition) of the Spaniards in 1619, the population had declined by half. Relating the unlucky attempt to convert the Roamainas and the Zaparos, Figueroa wrote that an outbreak of catharro, moquilla y mal de costado (catarrh, fever, pneumonia) and other diseases had reduced the initial population of about 2,000 indios de lanza (warriors, lanza being lance or spear), to only $300 .{ }^{20}$ In the latter part of the $17^{\text {th }}$ century, rebellions, repressions and flights kept in check the expansion of the mission's population. In 1719, in the 28 Missions there lived about 8,000 indios, including a few hundreds catechumenos, only one thousand more than those estimated by Figueroa in 1661, after the devastating smallpox epidemics, and notwithstanding the foundation of several new missions.

A synthesis of the population dynamic of the missions' indios can be found in table 1, where the total population of a varying number of missions

\footnotetext{
17 Figueroa, 1986 (1681): 160.

18 Ibidem: 239.

19 Ibidem: 241.

20 Ibidem: 233.
} 
is reported; the totals in the series are derived from a variety of sources, and refer to the 1719-1798 period. These enumerations consisted in cuadros sumarios (summary tables, prospects) for each individual mission compiled by the fathers or by the Visitors of the district, normally detailing a few categories such as the married, the unmarried, children and adolescents.

Table 1. Population of Mainas Missions, 1719-1798

\begin{tabular}{|c|c|c|c|c|c|}
\hline Year & $\begin{array}{c}\text { Indios } \\
\text { baptised }\end{array}$ & $\begin{array}{c}\text { Indios } \\
\text { neophite }\end{array}$ & $\begin{array}{c}\text { Total } \\
\text { Population }\end{array}$ & $\begin{array}{c}\text { Number of } \\
\text { Missions }\end{array}$ & $\begin{array}{c}\text { Population } \\
\text { per Mission }\end{array}$ \\
\hline 1719 & 7586 & 380 & 7966 & 28 & 285 \\
\hline 1727 & 5194 & 748 & 5942 & 22 & 270 \\
\hline 1740 & 9549 & 1487 & 11036 & 32 & 345 \\
\hline 1745 & 9976 & 2939 & 12915 & 41 & 315 \\
\hline 1760 & & & 12229 & 34 & 360 \\
\hline 1767 & 11620 & 154 & 11774 & 22 & 535 \\
\hline 1769 & 9131 & 32 & 9163 & 22 & 417 \\
\hline 1776 & 8857 & 70 & 8927 & 22 & 406 \\
\hline 1786 & & & 9111 & 22 & 414 \\
\hline 1798 & & & 4455 & 22 & 203 \\
\hline
\end{tabular}

Source: Golob, 1982: 203-04, tables 17, 20, 21 and 22.

The criteria for dressing these summary tables were more or less homogeneous, following the rules of the church and of the order; however the conditions under which the information was gathered were far from being uniform, and depended on the geography, the environment and the social dynamic of each individual mission. The life and nature of missions was varied: new missions were continuously created while others were abandoned; new ethnic groups came to live in already structured missions, while others took flight; several fathers had the responsibility of more than one mission; different missions were combined while others split. As said above, in 1719 about 8,000 indios lived in 28 missions, but renewed efforts for the evangelization of the Napo led to the foundation of many new missions, whose total number increased to 41 in 1745, with a total of almost 13,000 souls -both peak numbers for the entire period-. When the order was disbanded in 1767, the number of mis- 
sions had decreased to 22, with less than 12,000 indios. ${ }^{21}$ After the expulsion of the fathers, the population remained more or less constant for a while, but at the close of the century had dwindled to 4,500 .

For reasons already mentioned, the comparability of the series is insecure, and the data do not tell us much about the intrinsic dynamic of the mission population until the expulsion of the Jesuits, and under secular and then civil control in what remained of the century. An improvement on the comparability of the data is obtained in table 2: for each time interval, the comparison has been restricted to those same missions that were enumerated both in the initial and in the terminal year. Between 1719 and 1740, the population of 12 missions has been compared; between 1740 and 1745, 14 missions, and so on. The table reveals that during the Jesuit era, population growth was 1 percent per year, while after the expulsion a negative rate of growth sets in. In the missions existing both at the beginning (1719) and at the end (1776) of the period, aggregate population had increased by two thirds, with a rate of growth of 0.9 percent.

${ }^{21}$ Here below are reported the sources of the data for each individual mission, synthesized in tables 2 and 3, and in figure 5:

1719 - Biblioteca Nazionale Centrale, Roma, Fondo Gesuitico, nº 1249/1.

1727 - Archivo de la Compañia de Jesus, Quito, Informe de las Missiones del Marañon, que hace el P. Diego Gutierrez, de la C.nia de JHS al P. Ignacio Hormegui Provincial de la Provincia de Quito visitandola a 8 de Septiembre 1729 AD, leg. X, $\mathrm{n}^{\circ} 963$.

1740 - Archivio Propaganda Fide, Roma, Catalogus Missionum Gentilium Soc. Jesu in Provincia Quitensi Americana, Confectus anno 1740, America Meridionale, vol. 3 bis, fol. 479-80.

1745 - Archivo de la Compañia de Jesus, Quito, Visita por orden del Ill.mo S.D.D Andres de Paredes, Obispo de Quito, hizo el Dr. D. Diego Riofrio de Peralta a las Misiones año 1745, leg. XII, $\mathrm{n}^{\circ} 1110$.

1760 - Archivo de la Compañia de Jesus, Quito, Numero de los pueblos y gente que efectivamente se hallan en las Missiones Altas y Baxas del Marañon, Septiembre 1760, Padre Pedro Esquini, leg. XIV, no 1279.

1762 - Archivo de la Compañia de Jesus, Quito, Catalogo y numeración de los pueblos, 1762, leg. XIV, no 1294.

1767 - Biblioteca Nacional, Madrid, Inventario de la Laguna y otros pueblos de Mainas, Manuscrito $\mathrm{n}^{\circ} 17614$.

1769 - Rodolfo R. Schuller, "Documentos para la historia de las misiones de Mainas", Boletin de la Real Academia de la Historia, 59 (Madrid, noviembre 1911).

1776 - Idem. 
Table 2. Population change in Mainas Missions, 1719-1776

\begin{tabular}{|c|c|c|c|c|c|c|c|}
\hline $\begin{array}{c}\text { Initial and } \\
\text { terminal } \\
\text { date }\end{array}$ & $\begin{array}{c}\text { Population } \\
\text { at initial } \\
\text { date }\end{array}$ & $\begin{array}{c}\text { Population } \\
\text { at terminal } \\
\text { date }\end{array}$ & $\begin{array}{c}\text { Number of } \\
\text { Missions } \\
\text { Compared }\end{array}$ & $\begin{array}{c}\text { \% Popula- } \\
\text { tion chan- } \\
\text { ge between } \\
\text { initial and } \\
\text { terminal } \\
\text { date }\end{array}$ & $\begin{array}{c}\text { \% po- } \\
\text { pulation } \\
\text { change } \\
\text { per year } \\
\text { between } \\
\text { initial and } \\
\text { terminal } \\
\text { date }\end{array}$ & $\begin{array}{c}\text { Mean } \\
\text { Mission } \\
\text { population } \\
\text { at initial } \\
\text { date }\end{array}$ & $\begin{array}{c}\text { Mean } \\
\text { Mission } \\
\text { population } \\
\text { at terminal } \\
\text { date }\end{array}$ \\
\hline 1719,1740 & 8443 & 10623 & 12 & 25,8 & 1,09 & 704 & 885 \\
\hline 1740,1745 & 4964 & 5355 & 14 & 7,9 & 1,52 & 355 & 383 \\
\hline 1745,1767 & 5991 & 7817 & 13 & 30,5 & 1,21 & 461 & 601 \\
\hline 1767,1769 & 7998 & 7670 & 14 & $-4,1$ & $-2,09$ & 571 & 548 \\
\hline 1769,1776 & 8243 & 7909 & 17 & $-4,1$ & $-0,59$ & 485 & 465 \\
\hline 1719,1776 & 3406 & 5738 & & 68,5 & $1,03 *$ & 704 & 465 \\
\hline
\end{tabular}

Note: At each pair of dates, initial and terminal, the same Missions have been compared. During the 1719-40, population increased in 7 of the 12 Missions, declined in 4 and remained unchanged in 1. In the following periods, the number of Missions whose population increased, declined or remained unchanged was, respectively: 1740-45, 6, 7 and 1; 1745-67: 9, 4 and 0; 1767-69:8, 6 and 0; 1769-76: 3, 14 and 0.

* The Rate of increase $(1,03 \%)$ for $1719-76$ is the weighted average of the rates for with weights proportional to the number of years in each interval.

Let us assume that the mission subsets considered in table 2 were representative of the entire mission population. Now a rate of growth close to 1 percent could be considered as a symptom of a flourishing population, able to double its size in 70 years or so. This is a rhythm of growth seldom achieved -over the long run- by pre-modern populations, normally plagued by high mortality, as was the case of the native populations of America. Hence the crucial question: if the populations of the Amazonian basin suffered a demographic collapse -as a variety of indicators appear to confirm- why was the missions' population flourishing? Unfortunately we lack the detailed information that would, perhaps, solve the enigma, such as the registration of baptisms and burials. This information was almost certainly collected, since registrations of marriages, baptisms and burials were kept -as it is attested by several sources- but they have been lost, or dispersed, or ended up in smoke when a fire destroyed, in 1749, the general archive of the Jesuit missions that was kept in Santiago de la Laguna. We cannot therefore know whether 
the increase achieved during the $18^{\text {th }}$ century was due to an excess of births over deaths, or to an excess of neophytes newly immigrated over those that kept abandoning "the house of the father". However, a key to the solution of the enigma exists. We know that the fathers were engaged in a systematic action of exploration and contact with new ethnic groups, in the attempt of recruiting and attracting in the missions new souls to be converted. During the $18^{\text {th }}$ century, for instance, the fathers of the Misión Baja carried a series of consultations in view of the organization of an annual entrada, in search of new recruits in order to contrast the decline of the missions. ${ }^{22}$ In the mission of San Joaquin de Omagua some indios were regularly designated in order to escort the father whenever he organized an expedition, a symptom that this was a normal means of evangelization. ${ }^{23}$ In a long report relating the events of the period 1750-1761, father Widman (1764) informs about a number of expeditions organized by the fathers as well as the number of indios brought back to the missions. ${ }^{24}$ In those 12 years, he reports about 38 expeditions, with a total of 2692 indios captured, recruited or "convinced" to join the missions: an average of 71 indios per expedition. ${ }^{25}$ This amounts to an average of 228 indios being "induced" to join the missions in every passing year, equivalent to an immigration rate of 2 percent per year, or an immigrant for every two or three newborn. These numbers and ratios are presumably largely underestimated: not all the expeditions were noted by Father Widman, and many groups joined the missions "spontaneously" or, in any case, outside organized entradas. The anecdotal evidence points to a turnover of the population not as high as in the initial phase, as we shall see later, but very considerable. In spite of this inflow, the population of the missions was stationary over the period considered, evidence that the process of immigration was a major factor of the mission demographic system. That the system was in a continuous tension in order to keep in balance the repeated flights with the new recruitments, is attested by a number of reports and chronicles.

In the missions of Paraguay -in the valleys of the Paraná and Uruguay rivers- as well as in the Mojos missions in eastern Bolivia, after an initial phase of active evangelization, through ad hoc expeditions, proselytism was kept to a minimum and the missions thrived because of their own demographic dynamic. Mainas was a different case, its mobile and fluid way of life required

\footnotetext{
22 Jouanen, 1943: 501.

${ }^{23}$ Uriarte, 1952, I: 134.

${ }^{24}$ Widman, 1744.

${ }^{25}$ Golob, 1982: 275.
} 
a continuous action of recruitment in order to counteract their propensity to flee the order imposed by the fathers.

As to the population living outside the missions, only impressionistic evidence is available, pointing to a desertification of the riverbanks, to a decline of tribes once reputed to be numerous or to the outright disappearance of others -because of fusion with other groups, because of their outright extinction or because they moved into inaccessible areas-.

\section{Glimpses INTO THE AMAZONIAN DEMOGRAPHIC SYSTEM}

The mission data collected by the fathers during the $18^{\text {th }}$ century offer further elements for the analysis of Mainas demography. Not many indeed, also because the raw indicators of the age structure that can be calculated are of a limited use: indeed the mission's indios cannot be assimilated to a stable population, given the intense process of mobility, and not much can be inferred in terms of birth and death rates. ${ }^{26}$ The statistical summaries for each mission normally detailed the number of the married people, of the unmarried, of the widowed, of the adolescents and of the children - each category with gender specification-. It goes without saying that these categories, borrowed from the European society, had little meaning for the mission's indios, at least in the initial phase.

Married males and married females were equal in number (in practice, couples living in a stable union were counted); age limits of the various categories were certainly approximate; the distinction between the (adults) unmarried and widows and widowers was at times blurred. The number of married couples is assumed to be equal to the number of families, but these did not coincide with households: in many nations a household was composed of a plurality of families. Children were those below age 7, but in some cases inconsistencies are evident; the age limits of the adolescents were 7 and the age at puberty, lower for girls than for boys (presumably 14 and 16 years, as in other areas administered by the Jesuits). We assume that all adolescents married around the age of puberty (in other American missions adolescent girls married at 14-15, and adolescent men one or two years later), but exceptions were likely.

${ }^{26}$ A "stable population" is a population with no in- or out-migration, whose age structure does not change in time because it is determined solely by the levels of fertility and mortality, which are fixed in time. If a population is stable, the levels of fertility and mortality can be inferred if the age structure and the rate of growth are approximately known. This cannot be done for Mainas population, because of the high levels of migration in each individual mission. 
Table 3 assembles the data of 6 missions that are always present in the enumerations taken between 1740 and 1776, and comprising approximately two fifths of the entire mission population. The data of the six small missions have been collapsed in order to give more robustness to percentages and ratios. But even so, it is only a small population of a few thousand individuals, of the size of a few ancien régime parishes in Europe. The indicators of table 3 are quite similar to those of other mission populations; they are compared in table 4 with those calculated for the much larger population of Paraguay's and Mojos' missions of eastern Bolivia (at the headwaters of the Madera river, the main tributary of the Amazon), for approximately the same period.

Table 3. Structure of the Population of 6 Mainas Missions, ALWAYS ENUMERATED, 1740 TO 1776

\begin{tabular}{|l|c|c|c|c|c|}
\hline & $\mathbf{1 7 4 0}$ & $\mathbf{1 7 4 5}$ & $\mathbf{1 7 6 7}$ & $\mathbf{1 7 6 9}$ & $\mathbf{1 7 7 6}$ \\
\hline \multicolumn{3}{|c|}{ Population } \\
\hline Married Men & 744 & 804 & 1163 & 1221 & 1209 \\
\hline Married Women & 744 & 804 & 1163 & 1221 & 1209 \\
\hline Widowers & -- & 104 & 51 & 76 & 59 \\
\hline Widows & -- & 186 & 132 & 198 & 197 \\
\hline Unmarried, Men and Women & 256 & -- & -- & -- & -- \\
\hline Adolescent Males & 398 & 348 & 686 & 233 & 218 \\
\hline Adolescent Females & 312 & 372 & 453 & 147 & 129 \\
\hline Boys & 491 & 486 & 662 & 1088 & 1113 \\
\hline Girls & 499 & 466 & 693 & 1052 & 1063 \\
\hline Neophytes & 91 & 161 & 20 & -- & -- \\
\hline Total & 3530 & 3731 & 5023 & 5236 & 5198 \\
\hline & \multicolumn{5}{|l|}{} \\
\hline Members per family (a) & 4,74 & 4,64 & 4,32 & 4,29 & 4,30 \\
\hline Children per family & 1,33 & 1,18 & 1,17 & 1,75 & 1,80 \\
\hline Chlldren and Adolescents per family & 2,28 & 2,08 & 2,14 & 2,06 & 2,09 \\
\hline Males to Femals ratio (b) & 1,10 & 1,02 & 1,18 & 1,10 & 1,12 \\
\hline Widowers per 100 married men (c) & 17,2 & 18,0 & 7,9 & 11,2 & 10,6 \\
\hline Children per 100 population & 28,0 & 25,5 & 27,0 & 40,9 & 41,9 \\
\hline Young per 100 population (d) & 48,2 & 44,8 & 49,7 & 48,1 & 48,5 \\
\hline Married per 100 population & 42,2 & 43,1 & 46,3 & 46,6 & 46,5 \\
\hline Annual rate of population change (\%) & 2,08 & 1,11 & 1,35 & 2,06 & $-0,10$ \\
\hline
\end{tabular}

Notes: (a) Total population per married couple; (b) Excluded the unmarried; (c) For 1740, the unmarried were considered to be widowed; (d) Young is the sum of children and adolescents. 
The six missions are: Limpia Concepción Cahuapanes; S. Juan de Camichuros; Presentación de Chayabitas; Limpia Concepcion de Jeveros; S. Joaquin de Omaguas; and Nuestra Señora de las Nieves de Yurimaguas.

Families were small, 4.0 to 4.5 members on average; there were between 1.4 and 1.6 children per couple; children below age 7 were one third or more of the total population; married women represented almost half the female population. All these indicators are compatible with a "high pressure" demographic system, with high birth rates and high death rates, and good potential for growth in normal years that, however, in the turbulent history of the missions were neither frequent nor long lasting. ${ }^{27}$

Table 4. Paraguay, Mojos and Mainas' Missions: A comparison

\begin{tabular}{|l|c|c|c|}
\hline & $\begin{array}{c}\text { 30 Missions } \\
\text { of Paraguay } \\
\text { (Brazil, Paraguay, } \\
\text { Argentina) }\end{array}$ & $\begin{array}{c}\text { Mojos (Eastern } \\
\text { Bolivia) }\end{array}$ & $\begin{array}{c}\text { Mainas (Peru, } \\
\text { Ecuador) }\end{array}$ \\
\hline Period & $1733-67$ & $1720-64$ & $1740-1776$ \\
\hline Population & $78,000-105,000$ & $21,800-36,400$ & $3,500-5,200$ \\
\hline Percent Children & 37 & 35,7 & 32,7 \\
\hline Percent Married & 50,4 & 50 & 44,9 \\
\hline $\begin{array}{l}\text { Children per married } \\
\text { woman }\end{array}$ & 1,65 & 1,44 & 1,45 \\
\hline Persons per family & 4,48 & 4 & 4,45 \\
\hline Birth rate (per 1000) & 56,9 & 68,6 & NA \\
\hline $\begin{array}{l}\text { Death rate (per } \\
\text { 1000) }\end{array}$ & 44,3 & 47,9 & NA \\
\hline
\end{tabular}

Source: Livi-Bacci and Maeder, 2004. Livi-Bacci, 2010.

Paraguay: 1732-1767.

Mojos: average of $1720,1732,1736,1748,1752,1764$; birth rate and death rate: average 1828-30.

Mainas: average 6 missions, 1740, 1745, 1767, 1769, 1776.

${ }^{27}$ Among the Guaraní of the missions of Paraguay -and in the years not affected by epidemics and conflicts- the birth rate was around 55 per thousand and the death rate around 45 per thousand, equivalent to a number of children per woman (TFR) of 7-8, to an expectation of life at birth around 25 years and to a potential rate of growth of 1 percent or more (Livi-Bacci, 2008: 258-60). Amazonian demography was probably very similar. See also Jackson (2008). 
In the American missions the fathers placed at the heart of their conversion activity a few basic principles not to be subverted if a well ordered society was to be achieved. Marriage could not be dissolved, family life had to be private and promiscuousness had to be fought. The fathers knew well that these principles could not be imposed on adults who had been just dragged out from their traditional ways of life, and their strategy was to concentrate the efforts of indoctrination on children and adolescents in order to raise them as good Christians, obedient to the precepts concerning family life. They sought an implicit educational monopoly on the very young, and at the age of puberty the fathers supervised the arrangement of a proper marriage. In such a way, after the foundation of the mission, the first Christianized couples were rapidly formed. The action of the fathers encountered in Amazonia many more obstacles than in other parts of America: they were few in number in the immensity of the region; the population was highly mobile; and the missions were unstable villages. Only in the largest and more structured missions, such as Limpia Concepción de los Jeveros, Santiago de la Laguna or San Joaquin de Omaguas, we have evidence of a well organized and regular indoctrination of children, essential for the new religion to take solid roots.

\section{MOBILITY AND FRAGMENTATION}

Riverine populations were highly mobile. ${ }^{28}$ Travel on the waterways was easy for the native, experienced canoeist. Fifty miles a day could be easily covered downstream; upstream three days would have been needed to cover the same distance. The environment of the várzea was relatively homogeneous. Even for the agriculturalists village dwellers, moving a settlement to a different site was easy, new chacras (fields) for growing maize, manioc, squashes or bananas were readily prepared; fishing was abundant everywhere and so were the water turtles, prized for their eggs, fat and meat. The long distance migration of the Omaguas, Yurimaguas and other groups, are examples of the high mobility of the native populations. ${ }^{29}$ Steel tools

${ }^{28}$ All the considerations and conclusions relating to the demographic system of the Mainas populations are to be read against the complex anthropological background of the riverine populations. Just to name a few major references, the works of Steward, 1948a; 1948b. Sweet, 1974. Golob, 1982. Carneiro da Cunha, 1992. Roosevelt, 1994 have proved to be rich sources of facts, interpretations and ideas for the non-anthropologist author.

29 The migratory routes of Yurimaguas. Omaguas, Aizuaris, Ibanomas are described by Waltraub Grohs (Grohs, 1974). Famous is the materialization of 300 indios brasiles in the 
and implements -and particularly steel axes and wedges- were the strongest argument in the hands of the fathers for convincing dispersed tribes to congregate in a new missionary settlement, but a lack of these could as easily determine the disbanding of the new community. ${ }^{30}$ Anecdotal evidence is abundant and, in our eyes, at times extremely picturesque. High mobility goes hand in hand with the fragmentation of tribes or nations, and their small dimensions. Father Lucas de la Cueva and Figueroa recognized 40 or more of them, each with a different name, speaking different languages or different dialects; Chantre y Herrera ${ }^{31}$ indicates 49 different nations and more than 40 tongues spoken. Grohs, who has carried out a painstaking and thorough analysis of the literature, has documented the existence of 55 different groups, each one aware of its own identity and of the dividing lines with neighboring groups, with whom they were in competition and often in conflict. ${ }^{32}$ Heredia talks of 43 nations with lenguas matrices (matrix languages) and 128 dialects. ${ }^{33}$ Languages and dialects that often were mutually unintelligible. ${ }^{34}$ The Jesuits tried to impose in Mainas a common language -not Spanish, but quechua- in much the same way as the tupian lingua geral had been fostered by the Portuguese of the Parà in order to overcome the Babel of languages reigning in the Great River, reputed to be one of the main obstacles to evangelization. Fragmentation also implied very small dimensions for the various groups, from a few hundred to several thousand individuals at mid- $17^{\text {th }}$ century. Villages were normally small: most missions had between 200 and 400 inhabitants, but the indios outside the fathers' missions lived in smaller communities. The fathers struggled to group together different settlements, and knew that the cohesion of the communities depended also on their dimensions.

In summary, Upper Amazonian populations were very mobile; were distributed in many small groups, or tribes, or nations; furthermore, it is likely

\footnotetext{
Peruvian city of Chachapoyas, in November 1549: they were survivors of a group of several thousand indios Tupí that had fled from the coast of Pernambuco, and had navigated upstream the Amazon and the Huallaga.

${ }^{30}$ The possession of steel tools and implements (axes, wedges, knives...) multiplied native productivity in many major tasks (clearing a field, constructing a canoe, felling a tree, setting up a hut) by an order of magnitude or more, giving them also a considerable edge over competing groups. Steel, more than the Scriptures, was the decisive argument in the hands of the missionaries for converting the natives.

${ }^{31}$ Chantre y Herrera, 1901: 59-61.

32 Grohs, 1974.

${ }^{33}$ Heredia, 1924: 34.

34 Jouanen, 1943: 91-93. Veigl, 1986.
} 
that the processes of fission, mergence and extinction were rather intense. The Iberian intrusion, even under the eminently non-violent action of the Jesuits, determined an acceleration of the natural processes of mobility of the population and replacement of groups.

TABle 5. BAPTISMS OF HEATHENS AND TURNOVER OF VILLAGE POPULATION

\begin{tabular}{|l|c|c|c|c|c|c|}
\hline \multicolumn{1}{|c|}{ Missions } & Period & $\begin{array}{c}\text { Mission- } \\
\text { years (per } \\
\text { Mission) }\end{array}$ & $\begin{array}{c}\text { Baptisms } \\
\text { of heathens } \\
\text { over the } \\
\text { period }\end{array}$ & $\begin{array}{c}\text { Baptisms of } \\
\text { heathens per } \\
\text { year }\end{array}$ & $\begin{array}{c}\text { Estimated } \\
\text { average } \\
\text { population }\end{array}$ & $\begin{array}{c}\text { \% Gross } \\
\text { village } \\
\text { turnover }\end{array}$ \\
\hline $\begin{array}{l}\text { San Francis- } \\
\text { co de Borja }\end{array}$ & $1636-86$ & 51 & 22800 & 447 & 1500 & 29,8 \\
\hline $\begin{array}{l}\text { Limpia } \\
\text { Concepcion } \\
\text { de Jeveros }\end{array}$ & $1640-86$ & 47 & 22320 & 475 & 1500 & 31,7 \\
\hline $\begin{array}{l}16 \text { small } \\
\text { Missions }\end{array}$ & $\begin{array}{l}\text { Various } \\
\text { periods }\end{array}$ & 26 & 58200 & 2271 & 5000 & 45,4 \\
\hline Total & & $\mathbf{1 2 4}$ & $\mathbf{1 0 3 3 2 0}$ & $\mathbf{3 1 9 3}$ & $\mathbf{8 0 0 0}$ & $\mathbf{3 9 , 9}$ \\
\hline
\end{tabular}

Source: Razon y Noticias de las reducciones y pueblos de los convertidos y bautizados, segun consta de los autos de visita de dichas Iglesias y Pueblos, de Antonio Garcia Ceares, cura y vicario de Santiago de la Montañas, por Comision del Sen. Ill.mo Don Alonso de la Peña Monte Negro, Obispo de Quito, 1697, Archivo de la Compania de Jesus, Quito (ACJ), leg. V, nº 480.

Note: "Baptisms of heathens" are all baptisms declared to the emissary of Bishop Montenegro, and (presumably) include also baptisms to new born babies in (punto y seguido) the Missions. "Gross turnover" is the \% ratio of all baptisms to the village population. A "net turnover" can also be estimated deducting from all baptisms. The estimated number of babies born in the village (about 60 per thousand population).

Net turnover would than be $23,8 \%$ for Borja, $25,7 \%$ for Limpia Concepcion, (punto y seguido) $39,4 \%$ for the 16 small missions, $33,9 \%$ for the entire region.

Table 5 supplies an indirect proof of the above. In 1687, Peña Montenegro, Bishop of Quito (the dioceses from which Mainas depended) sent a visitor to investigate the progress of what he thought a rather precarious action of evangelization carried out by the Jesuits. The visitor, Don Antonio Garcia de Zeares "priest and vicar of the city of Santiago de la Montaña" was also to collect the total number of baptisms from the parish books of each mission, from its inception to 1686 . Baptisms referred not only to the newborn but also to children, adolescents or adults when converted to the new faith. Although the statistics set down by the visitor are often suspiciously 
given in round numbers, he explicitly states, when visiting a mission, that he has inspected the books. "I inspected this church, the altar, the books, according to which, if there are no errors, it appears that there have been baptized...8095 souls..." 35 So the statistics appear to be the result of a hasty calculation rather than an outright invention of a careless inspector. Let us take the case of the largest mission, that of Limpia Concepción de Jeveros, where the Visitor counted 22,320 baptisms over the 47 years of life of the mission; 475 baptisms per year to an average population of 1,500 souls. The ratio baptisms/population (31,7 percent) can be defined as a "gross turnover" of the village, or the number of new village members per year and per hundred persons living in the mission. This measure can be refined, and a "net turnover" can be calculated, retaining only the baptisms of heathens joining the mission with the exclusion of the children born in the village (even considering a very high birth rate of 60 per thousand, they would amount to 90 per year). The "net turnover" (385/1500) was 25,7 percent; in other words, during the 47 years, about one fourth of the village population was annually "renewed" by new individuals joining the mission which replaced an approximately equal number leaving or fleeing the mission. By this calculation, net turnover for the entire mission system was, in each passing year, about one third. This extremely high turnover was probably connected with the initial phase of the construction of the mission system. "It happens" wrote the Visitor "that often a village has many people, and tomorrow one

${ }^{35}$ Razon y Noticias de las reducciones y pueblos de los convertidos y bautizados, segun consta de los autos de visita de dichas Iglesias y Pueblos, de Antonio Garcia Ceares, cura $y$ vicario de Santiago de la Montañas, por Comision del Sen. Ill.mo Don Alonso de la Peña Monte Negro, Obispo de Quito, 1697, Archivo de la Compania de Jesus, Quito (ACJ), leg. $\mathrm{V}, \mathrm{n}^{\circ} .480$.

${ }^{36}$ The turnover in the first phase of the mission's life is apparently much higher than the implicit turnover calculated for the period 1750-61, with an immigration rate of only 2 percent. If the interpretation I give of Garcia Zeares' statistics of baptisms is correct, it is possible that they had been inflated in order to magnify the success of the evangelization effort. As a consequence, also the turnover calculated in table 5 would have been overestimated. However, this high turnover reflects the more precarious conditions of the first phase of evangelization. On the other hand, as pointed out in the discussion of father Widman's report, the immigration rate of 2 percent is calculated on the indios "recruited" in more or less official expeditions, and reflects only a part of the recruitment of mostly heathen indios. Large part of migration -in the mature phase of the Missions- was through the relocation of already Christianized indios, moved from one place to the other, in a (more or less) voluntary way. 
will hardly find the third part of them, for only with presents and gifts can the fathers keep them, which costs them a great deal". ${ }^{37}$

In the $18^{\text {th }}$ century the fragmentation of the Maina population, becomes evident in the mission system. Several ethnic groups were often reunited in the same mission to avoid that too small a population would endanger the stability of the community. This process was not new: in the preceding century, in Limpia Concepción de Jeveros, beside the Jeveros themselves, lived Alabonos, Jivaros, Ticunas, Barbudos, Yameos and Ataguates. Father Lucero founded Santiago de la Laguna bringing together Cocamas, Chepeos and Xitipos. In San Joaquin de Omaguas, in 1756, lived together with the Omaguas, Migueanos, Amaonos, Mayorunas, Masamaes, Yurimaguas, Cocamas. In the same year, the mission of Pebas counted five different tribes, for a total of 650 inhabitants. Father Magnin wrote that in Borja, beside a few Spanish families and a small number of mestizos and mulattos, lived only 234 inhabitants, belonging to 17 different ethnic groups that he names one by one. Many of them only had one representative family.

\section{THE “LIQUID” PARADIGM}

The small size of ethnic groups, their fragmentation and their high mobility, in combination with the population decline brought about by the Iberian intrusion, may have had a further depressive impact on the Amazonian demography. The logic of the argument is relatively simple: the survival of an ethnic group in relative isolation depends, among other factors, on its size and on its age and sex composition. A small population of a few dozen individuals has little chance of surviving as a group: hazard may seriously distort the sex ratio at birth, or in the reproductive ages; or alter the age distribution in an unsustainable way. There might be too few individuals in the reproductive ages, diminishing the chances of finding a suitable mate. External events of natural or human origin- may damage the demographic structure beyond repair. Mutual assistance, division of labor and cooperation may be more difficult. Biologists, demographers and ecologists have coined the expression of "minimum population", or "minimum viable population", as the population size below which the probability of survival of the population as a group over

${ }^{37}$ Razon y Noticias de las reducciones y pueblos de los convertidos y bautizados, segun consta de los autos de visita de dichas Iglesias y Pueblos, de Antonio Garcia Ceares, cura $y$ vicario de Santiago de la Montañas, por Comision del Sen. Ill.mo Don Alonso de la Peña Monte Negro, Obispo de Quito, 1697, ACJ, leg. V, nº 480. 
Figure 3. Vunerability (RisK of EXTINCTION) OF SMALl POPUlations IN RELATION TO SIZE

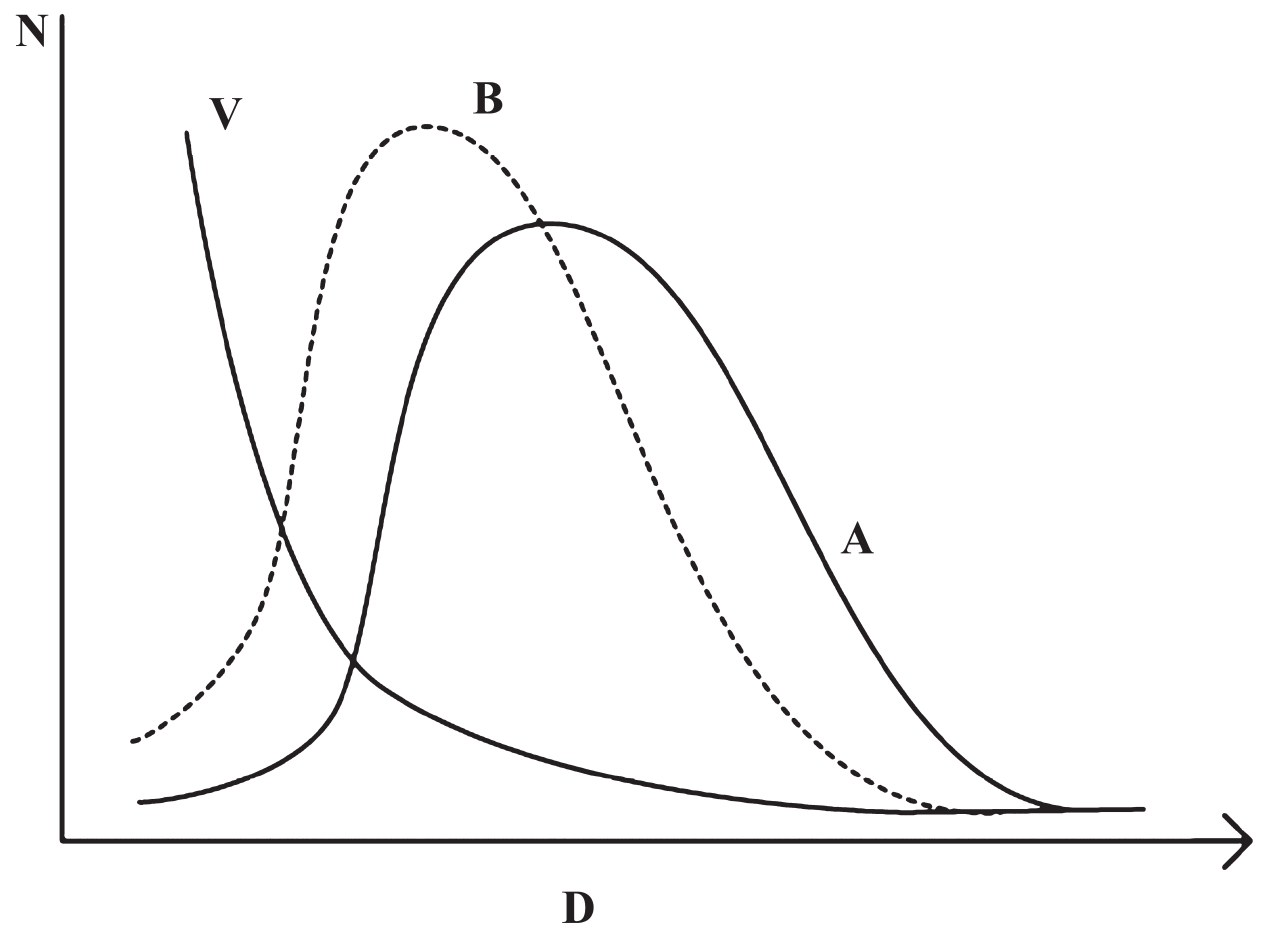

a long period of time starts declining. The minimum size of a population depends on many factors, but the literature indicates a few hundreds individuals (between, say, 100 and 500) as a reference number. Population decline and fragmentation in Amazonia, where autonomous groups were many and small, must have brought an increasing proportion of groups below the minimum threshold, adding an extra impulse to population decline. On the other hand, there is some evidence that fragmentation and flights caused by the Iberian presence, increased interethnic divisions and conflicts, and damaged the existing exchange networks based on trust and friendship. ${ }^{38}$

Figure 3 outlines this process. $(\mathrm{N})$ is the relative distribution of groups and (D) is the population size; (V) is vulnerability, or probability of extinction, that declines as size (D) increases. (A) is the distribution of groups by size in normal times, while (B) is the distribution during the process of population

${ }^{38}$ Golob, 1982: 260-70. 
decline. As the curve moves from A to $\mathrm{B}$, the proportion of highly vulnerable groups increases and, by consequence, also the proportion of groups that become extinct increases as well.

The scheme outlined in figure 3 is an abstract model: the scanty Maina data for the $18^{\text {th }}$ century may offer some indirect support to the theory. We will return to the population summaries available for 1740, 1745, 1767, 1769 and 1776 for a variable number of missions (table 3 ). For each mission, and for each date, four indicators have been selected:

1) The sex ratio of the population.

2) The proportion married.

3) Surviving children per married couple.

4) The proportion of children and adolescents.

Bearing in mind the approximation of the classifications (age, marital status) introduced by the fathers, one must remember that the indicators are not independent one from the other; 1) and 2) are related, because an unbalanced sex ratio reflects negatively on the proportion of stable (married) couples. The proportion married (2) is also positively related with the number of children per couple (3) and with the proportion of children and adolescent (4). However, all four indicators are indirect measures of the viability of a population and, therefore, of its vulnerability, as outlined in figure 3. In the four panels of figure 4 each indicator is plotted against the numerical size of the mission. One aspect is obvious -and was to be expected-: the smaller the population size, the higher the frequency of the missions whose indicators reflect a structural weakness. Take figure $4 \mathrm{a}$, where the sex ratio is plotted against the village size: with less than 400 inhabitants, many villages have a highly abnormal sex ratio (below 50 or above 200), and therefore a high vulnerability. Many smaller villages have also a very low proportion married, an extremely low ratio of children to stable couples, a low proportion of children and adolescents: all indicators of a vulnerable demographic structure. The opposite is true for larger villages -say, above 500 inhabitants- that seldom show ratios and proportions not in line with that "high pressure" demographic system, with high birth rates and high death rates, but with a good potential of growth in normal years, that was prevalent among the native populations of America.

We have defined the process set in motion by the encounter of the Iberians with the Amazonian populations as the 'liquid paradigm'. Liquid was the environment, with its rich network of waterways. Highly mobile were the native populations: "Purely individual flights and transculturation clearly went on constantly during the era of the reductions. Sometimes the fugitive would assimilate into groups that were still independent, or regroup to form small 
Figure 4. VitAl DEMOGRAPHIC RATIOS AND MISSION'S POPULATION Size (1740, 1745, 1767, 1769 AND 1776)
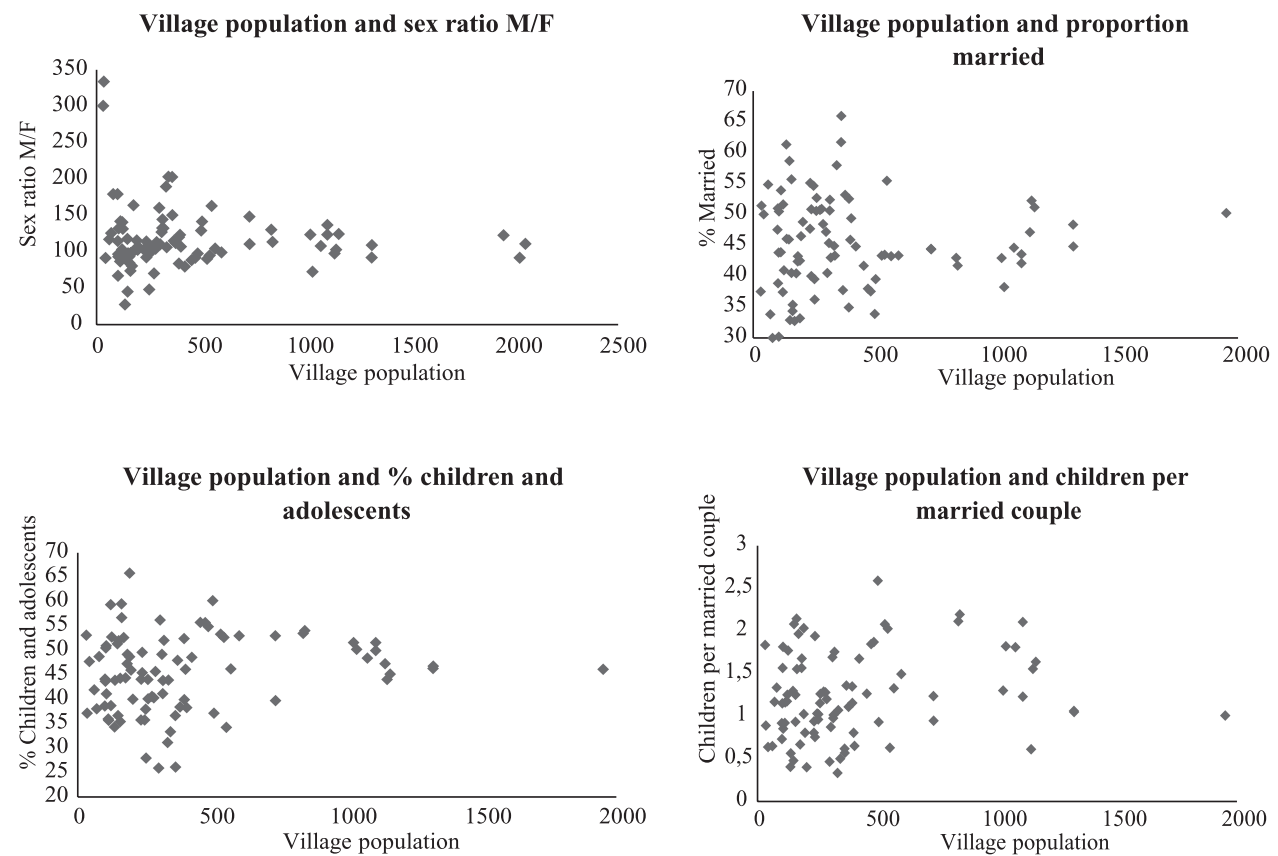

short-lived cells in unsettled areas". ${ }^{39}$ Overstretched and by necessity flexible was the Jesuit action, with their incessant work of founding and re-founding missions, of often precarious and ephemeral life. Mobile were the fathers, often in charge of more than one mission, that needed frequent replacement given the stressful life they led. Dislocation away from the riverine areas and into less favorable environments, fragmentation and increased general vulnerability of the communities, added to the force of the other factors that, elsewhere, determined the demographic collapse of the native Americans after contact. ${ }^{40}$

39 Taylor, 1999: 233-34.

${ }^{40}$ It may be worth reaffirming, here, that Eurasian diseases -in Amazonia as well as elsewhere in the continent- were important (in many cases predominant) factors of the catastrophe. But research must -as far as possible- clarify the impact of all possible concurring factors of depopulation. Dislocation and fragmentation, by weakening the resilience of the various tribal groups, may have had the double negative effect of lowering fertility and increasing the impact of the new viral pathologies. The analysis of the complexity of the catastrophe in Amazonia and in other American settings does not mean reviving the Black Legend, as some supporters of an oversimplified epidemiological paradigm believe. 


\section{REFERENCES}

Almesto, Pedro Arias de, "Jornada de Omagua y Dorado", Gaspar Carvajal, Pedro Arias de Almesto y Alonso Rojas, La aventura del Amazonas, Madrid, Dastin, 2002: 89-207.

Carneiro da Cunha, Manuela, (ed.), Historia dos Indios no Brasil, Säo Paulo, Companhia das Letras, 1992.

Carvajal, Gaspar, "Relación que escribió Fr. Gaspar de Carvajal, del nuevo descubrimiento del famoso Rio Grande", Gaspar Carvajal, Pedro Arias de Almesto y Alonso Rojas, La aventura del Amazonas, Madrid, Dastin, 2002: 31-88.

Chantre y Herrera, Juan, Historia de las Misiones de la Compañía de Jésus en el Marañón Español (1637-1767), Madrid, Imprenta de A. Aurial, 1901 (1770).

Denevan, William H. (ed.), The Population of America in 1492, Madison, The University of Wisconsin Press, 1992.

Denevan, William H., "The Native Population of Amazonia in 1492 Reconsidered", Revista de Indias, LXIII/227 (Madrid, 2003): 175-88.

Denevan, William H., "Estimating Amazonian Indian Numbers in 1492", Journal of Latin American Geography, 13/2 (Texas, 2014): 207-21.

Dobyns, Henry F., "An Appraisal of Techniques with a New Emispheric Estimate", Current Anthropology, 7/4 (Chicago, October 1966): 395-499.

Figueroa, Francisco, "Informe de las misiones del Marañon, Gran Pará o Rio de las Amazonas", Francisco Figueroa, et al., Informes de Jesuitas en el Amazonas, 1600-1684, Iquitos, IIAP-CETA, 1986 [1681]: 143-309.

Golob, Ann, "The Upper Amazon in historical perspective", Ph. D thesis, City University of New York, Ann Arbor, University Microfilm International, 1982.

Grohs, Waltraub, Los Indios del Alto Amazonas del Siglo XVII al XVIII. Poblaciones y migraciones en la antigua provincia de Maynas, Bonn, EstudiosAmericanistas, 1974.

Hemming, John, Tree of Rivers. The Story of the Amazon, Thames \& Hudson, New York, 2008.

Henige, David, Numbers from Nowhere: The American Indian Contact Population Debate, Norman, University of Oklahoma Press, 1998.

Heredia, José Felix, La antigua provincia de Quito de la Compañia de Jesús y sus misiones entre infieles, 1566-1767, Riobamba, Ecuador, 1924.

Hortegón, Diego, "Relaciones del estado en que se encuentra la gobernación de Quito y la Canela", Diego Hortegón et al., La gobernación de los Quijos (1559-61), Quito, Instituto de Historia y Antropología Andina, 1989: 257-272. 
Jackson, Robert H., "The Population and Vital Rates of the Jesuit Missions of Paraguay, 1700-1767“, Journal of Interdisciplinary History, XXXVIII/3 (Cambridge, Winter 2008): 401-31.

Jouanen, José, Historia de la Compañia de Jesús en la antigua provincia de Quito, 1570-1774, vol. 1, La vice provincia de Quito, 1570-96, Quito, Editorial Ecuatoriana, 1941.

Jouanen, José, Historia de la Compañia de Jesús en la antigua provincia de Quito, 1570-1774, vol. 2, La vice provincia de Quito, 1596-1773, Quito, Editorial Ecuatoriana, 1943.

La Condamine, Charles-Marie de, Voyage sur l'Amazone, Paris, Maspero, 1981 [1745].

Laureano de la Cruz, Fray, Nuevo descubrimiento del Río de Marañon llamado de las Amazonas, Madrid, La Irradiacion, 1900 (1651).

Livi-Bacci, Massimo, "The depopulation of Hispanic America after the Conquest", Population and Development Review, 32/2 (New York, 2006): 199-232.

Livi-Bacci, Massimo, Conquest. The Destruction of American Indios, Cambridge, Polity Press, 2008.

Livi-Bacci, Massimo, El dorado in the marshes. Gold, slaves and souls between the Andes and the Amazon, Cambridge, Polity Press, 2010.

Livi-Bacci, Massimo, Amazzonia. L’impero dell'acqua, 1500-1800, Bologna, Il Mulino, 2012.

Livi-Bacci, Massimo and Maeder, Ernesto J., "The Missions of Paraguay: The Demography of an Experiment", Journal of Interdisciplinary History, 35/2 (Autumn 2004): 185-224.

Lotka, Alfred J., Elements of physical biology, Baltimore, Williams and Wilkins, 1925.

Maroni, Pablo, Noticias autenticas del famoso Rio Marañon, Jean Pierre Chaumeil (ed.), Iquitos, IIAP-CETA, 1989.

Porro, Antonio, "Os Omaguas do Alto Amazonas. Demografia e Padroes de Povoamento no seculo XVII", Contribuçoes a antropologia em homenagem ao Professor Egon Schaden, São Paulo, Coleçao Museu Paulista, 1981: 207-231. Serie Ensaios, 4.

Roosevelt, Anna, “Arqueologia Amazonica”, Manuela Carneiro da Cunha (ed.), Historia dos Indios no Brasil, São Paulo, Companhia das Letras, 1992: 53-87.

Roosevelt, Anna, (ed.), Amazonian Indians. From Prehistory to the Present, Tucson, The University of Arizona Press, 1994.

Steward, Julian H. (ed.), Handbook of American Indians, vol. 3, The Tropical Forest Tribes, Washington, United States Government Printing Office, 1948a. 
Steward, Julian H., "Tribes of the Montaña: an Introduction", Julian H. Steward (ed.), Handbook of American Indians, vol. 3, The Tropical Forest Tribes, Washington, United States Government Printing Office, 1948b: 507-34.

Sweeet, David G., "A reach realm of nature destroyed. The middle Amazon valley, 1740-50", Ph. D. thesis, The University of Wisconsin, Ann Arbor, University Microfilms International, 1974.

Taylor, Anne Christine, "The Western Margin of Amazonia from the Early Sixteenth to the Early Nineteenth Century", Frank and Stuart B. Schwartz (eds.), The Cambridge History of the Native People of the Americas. III, South America, vol. II, Salomon, Cambridge, Cambridge University Press, 1999: 188-256.

Uriarte, Manuel J., Diario de un Misionero de Mainas, 2 vols, Costantin Bayle (ed.), Madrid, Instituto Santo Toribio Mogrovejo, 1952.

Vázquez, Francisco, Jornada de Omagua y Dorado. Cronica de Lope de Aguirre, el Peregrino, Madrid, Miraguano, 1979.

Veigl, Francisco Xavier, Noticias detalladas sobre el estado de la Provincia de Maynas en América Meridional hasta el año de 1768, Iquitos, CETA, 2006.

Velasco, Juan de, Historia moderna del rejno de Quito y cronica de la provincia de la Compañia de Jesus en el mismo Reyno, 3 vols., Quito, 1942.

Volterra, Vito, "Variations and Fluctuations of the Number of Individuals in Animal Species Living Together", Journal du Conseil International pour l'exploration de la mer, vol. 1, International Council for the Exploration of the Sea, 1928: 3-51.

Widman, Adam, Apuntes de la cosa más memorable que pasan y pasaron en la Misión desde el año 1744..., [1762], Madrid, Universidad Pontificia de Comillas. Colección Pastells, serie negra, vol. 108: 49-74.

Fecha de recepción: 3 de marzo de 2014.

Fecha de envío de las modificaciones: 6 de noviembre de 2014.

Fecha de aceptación: 14 de noviembre de 2014. 


\section{La despoblación en el Alto Amazonas en tiempos coloniales}

En el Alto Amazonas, después de la desastrosa penetración inicial de los colonos españoles, los jesuitas empezaron la tarea de evangelización en 1638. Una red de misiones cubrió todo el territorio y se recogieron estadísticas. El sistema demográfico indígena se caracterizó por su alta movilidad y la gran fragmentación de algunas comunidades, además de por la rápida rotación de la población de las misiones. La intrusión ibérica aumentó esta fragmentación y muchas naciones migraron fuera de las zonas ribereñas (várzea) hacia la selva, donde las condiciones de vida eran menos favorables. Puede que este proceso empujara a muchas comunidades por debajo del umbral mínimo de la viabilidad y acelerase el colapso demográfico.

Palabras Clave: Alto Amazonas; Mainas; Misiones; Demografia; Movilidad; descenso de población. 